\title{
ON THE ORIGIN OF POT-HOLES
}

\author{
By KNUT FæGRI \\ (Universitetet i Bergen)
}

IN geological text-books the explanation is generally given that pot-holes are formed by semipermanent moulins which occur where the glacier breaks over a sharp edge. Consequently there will be a semi-permanent crevasse through which water falls more or less vertically down on to the glacier bed.

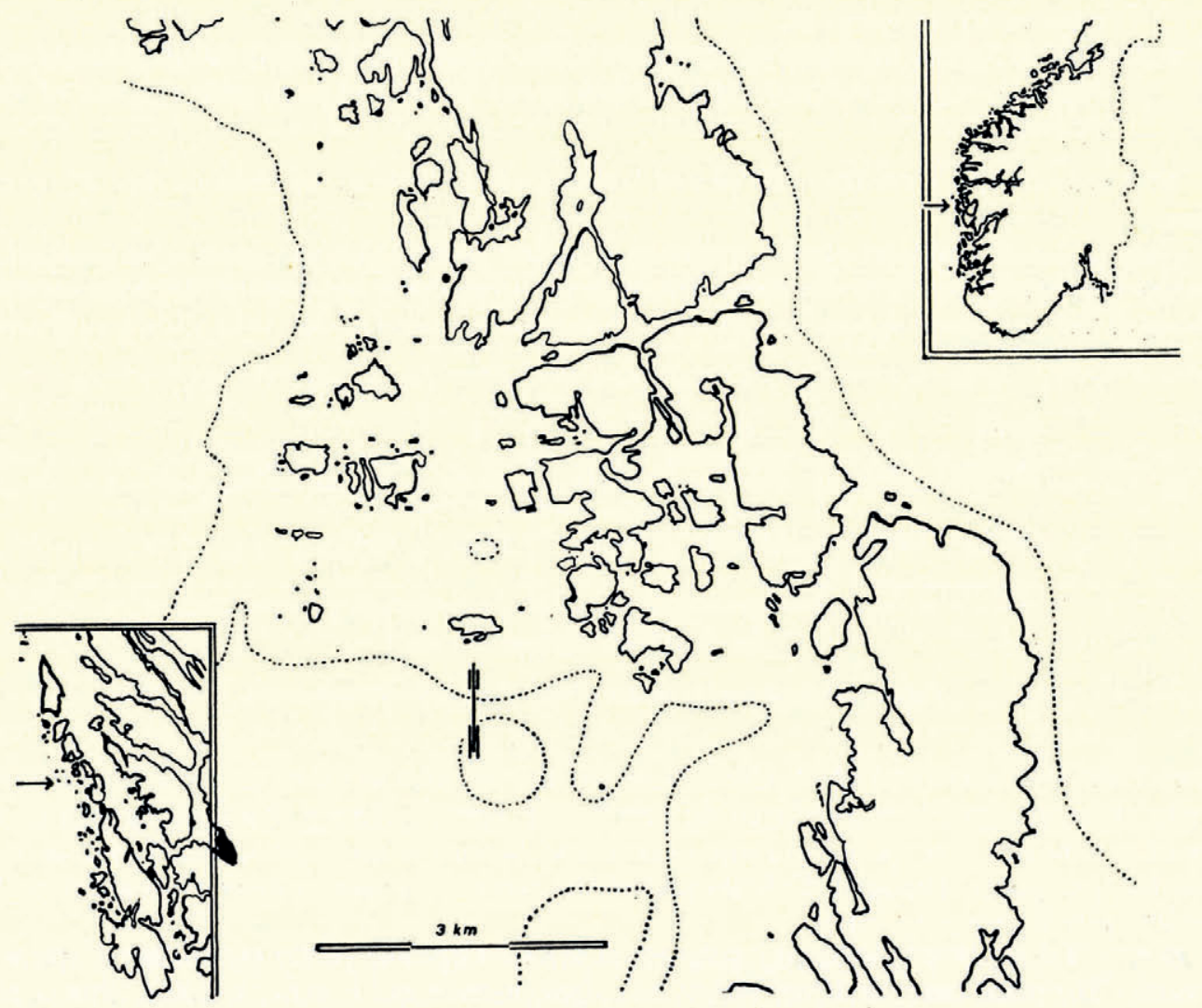

Fig. 3. Kvannholmen and surroundings. Depth contour $100 \mathrm{~m}$. indicated in the main map. The black area outside the frame of the lower inset map is the town of Bergen. Reproduced with permission from Topografisk kart over Norge, Herdla, edited by Norges geografiske Oppmåling

In a recent issue of the Fournal of Glaciology (Vol. I, No. 9, p. 488-90) Dr. R. Streiff-Becker contends that pot-holes are not produced in this manner.* I shall not try to prove that the old hypothesis covers all cases - in fact, very much seems to indicate that pot-holes may be formed in different ways, even if we restrict ourselves to holes with a vertical axis-but I should like to draw attention to one particular group of pot-holes where I think the old explanation fits in better with observations than any other hypothesis.

* In a letter (Vol. r, No. ro, October 1951, p. 582) Dr. Streiff-Becker qualifies this statement.-Ed. 
The locality is a small, exposed ocean island west of Bergen, Norway, called Kvannholmen (parish of Herdla), near the very top of which (height $23 \mathrm{~m}$.) there is a group of quite good potholes. The one illustrated in Fig. I (p. 20) is 3.20 m. deep with a diameter of 1 m. Fig. 2 (p. 20) shows the location on the island, and Fig. 3 (p. 24) the position in relation to the surrounding country. Comment is hardly necessary; it will be seen that the location of the pot-holes is very easily explained by the old theory, but is in hopeless antagonism to Streiff-Becker's assumption. No sub-glacial stream could run across this island as long as there were excellent outlets just north and south of it - and besides, the main outlet goes north-west on the other side of the chain of islands.

The assumption that these pot-holes have been formed during an earlier glaciation and have remained while the drainage pattern has changed fundamentally, must be rejected as totally improbable. In late-glacial times the island was submerged and emerged again. We must assume that the erosion that is seen in Fig. I (front part of pot-hole broken away), and which has cut another hole in half lengthwise, took place during this period.

MS. received 17 Fuly $195 \mathrm{I}$

\title{
REPORT ON THE SNOW SURVEY OF GREAT BRITAIN FOR THE SEASON I 950-5I
}

\author{
By E. L. Hawke and D. L. Champion
}

As in the previous few years, this report is based principally on returns furnished month by month by an able body of volunteer observers working in collaboration with the Society. There are now some 300 of these. About 50 per cent of them report from land stations well distributed over England, Wales and Scotland (with one representing the neighbourhood of the Mourne Mountains in Northern Ireland), the remainder from lighthouses, light-vessels and merchant ships voyaging in coastal waters. Important supplementary material comes from the serial publications of the Meteorological Office, Air Ministry, and from manuscript data kindly supplied by that Department. Further valuable sources of information are the logs and diaries of individual climbers and leaders of expeditionary parties who study mountain snow conditions as opportunity offers. On this occasion special tribute must be paid to the services of Mr. M. J. Wilkinson (Durham University Exploration Society), Mr. R. G. Sandeman of Crickhowell and Mr. T. J. Ransley of Fort William, the results of whose labours bulk largely in the report. To these gentlemen as well as to all other collaborators-the private observers, the Director of the Meteorological Office and his staff, the Elder Brethren of Trinity House with their lighthouse and lightship personnel, and the many shipping companies whose ships' reports help to extend the observational network around our shores-the directors of the Survey express their most cordial thanks for the assistance given them.

E. L. H.

$\begin{array}{rlr} & \text { Metric Equivalents of INCHES AND FEET } \\ \text { I in. }=0.025 \mathrm{~m} . & \mathrm{I} \mathrm{ft.}=0.305 \mathrm{~m} . \\ 3 \mathrm{in} .=0.076 \mathrm{~m} . & 2 \mathrm{ft} .=0.609 \mathrm{~m} . \\ 6 \mathrm{in} .=0.152 \mathrm{~m} . & 4 \mathrm{ft} .=1.219 \mathrm{~m} . \\ 100 \mathrm{ft} .=30.5 \mathrm{~m} . & 2500 \mathrm{ft} .=762.0 \mathrm{~m} . \\ 500 \mathrm{ft} .=152.4 \mathrm{~m} . & 3000 \mathrm{ft} .=914.4 \mathrm{~m} . \\ 1000 \mathrm{ft} .=304.8 \mathrm{~m} . & 3500 \mathrm{ft} .=1066.8 \mathrm{~m} . \\ 1500 \mathrm{ft} .=457.2 \mathrm{~m} . & 4000 \mathrm{ft} .=1219.2 \mathrm{~m} . \\ 2000 \mathrm{ft} .=609.6 \mathrm{~m} . & \end{array}$

In general measurements of snow-depth cited in this Report refer to og.०o hr. G.M.T., or thereabouts. 